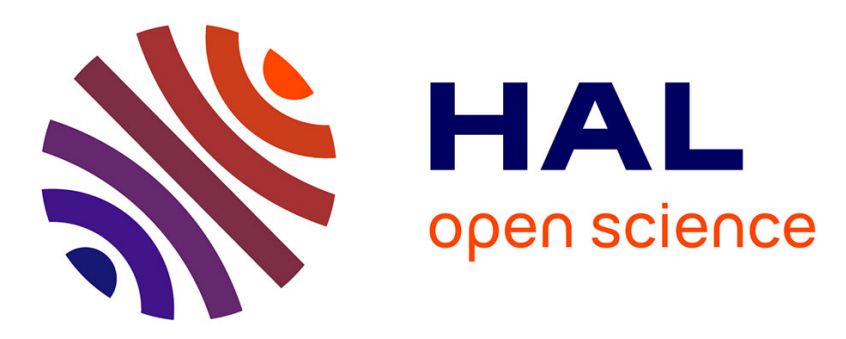

\title{
The whereabouts of $2 \mathrm{D}$ gels in quantitative proteomics
}

\author{
Thierry Rabilloud, Cécile Lelong
}

\section{To cite this version:}

Thierry Rabilloud, Cécile Lelong. The whereabouts of 2D gels in quantitative proteomics. Marcus K., Eisenacher M., Sitek B. Quantitative Methods in Proteomics Part of Methods in Molecular Biology, 2228, Humana, New York, NY, pp.41-51, 2021, 978-1-0716-1024-4. 10.1007/978-1-0716-1024-4_4 . hal-03228001

\section{HAL Id: hal-03228001 \\ https://hal.science/hal-03228001}

Submitted on 21 Sep 2021

HAL is a multi-disciplinary open access archive for the deposit and dissemination of scientific research documents, whether they are published or not. The documents may come from teaching and research institutions in France or abroad, or from public or private research centers.
L'archive ouverte pluridisciplinaire HAL, est destinée au dépôt et à la diffusion de documents scientifiques de niveau recherche, publiés ou non, émanant des établissements d'enseignement et de recherche français ou étrangers, des laboratoires publics ou privés. 
This document is an author version of a chapter published in Methods in Molecular Biology (2021) under the doi: 10.1007/978-1-0716-1024-4_4

The whereabouts of $2 \mathrm{D}$ gels in quantitative proteomics

Thierry Rabilloud and Cécile Lelong

Chemistry and Biology of Metals, Univ.Grenoble-Alpes, CNRS UMR5249, IRIG-DIESECBM, CEA Grenoble, 17 rue des martyrs, F-38054 Grenoble Cedex 9, France

thierry.rabilloud@cea.fr

Running head: Quantitative 2D-PAGE

Abstract:

Two-dimensional gel electrophoresis has been instrumental in the development of proteomics. Although it is no longer the exclusive scheme used for proteomics, its unique features make it a still highly valuable tool, especially when multiple quantitative comparisons of samples must be made, and even for large samples series. However, quantitative proteomics using two-dimensional gels is critically dependent on the performances of the protein detection methods used after the electrophoretic separations. This chapter therefore examines critically the various detection methods, (radioactivity, dyes, fluorescence and silver) as well as the data analysis issues that must be taken into account when quantitative comparative analysis of two-dimensional gels is performed.

ii. Key Words: 2D-PAGE, fluorescence dyes, image analysis, organic dyes, polyacrylamide gels, quantification, radioisotopes, silver staining 


\section{Introduction}

Since its introduction in the mid-seventies [1, 2], 2D electrophoresis has always been used as a quantitative technique of protein analysis, and it is fair to say that such quantitative analyses (e.g. in [3-8] ) have preceded the real onset of proteomics, hallmarked by the first protein identification techniques, at that time based on Edman sequencing [9-13]. In the current proteomics landscape, completely dominated by tandem mass spectrometry $[14,15]$, and where 2D gel-based proteomics is now perceived for only niche applications [16], it represents an exception in the sense that this is a proteomics setup where:

i) protein quantification is not made in a mass spectrometer (and there has been only very limited attempts to break this rule [17] )

ii) the on-gel quantification step is often used as a screening process to select a limited set of protein spots of interest, that are then further characterized by mass spectrometry, thereby limiting the mass spectrometry analysis time.

These two cardinal features put an enormous pressure on the performances that the ongel protein detection methods must show, as it is quite clear that what is not detected is never analyzed and thus completely ignored. Thus, the on-gel protein detection methods must be very sensitive, but also linear in response (to be able to detect accurately abundance variations), homogeneous (so that all classes of proteins are detected) and of course fully compatible with mass spectrometry (to ensure easy and accurate protein characterization).

Although these constraints have been quite clear to the community for numerous years, and have led to the implementation of many protein detection schemes, an often overlooked problem is the performance of the 2D electrophoresis itself. In other words, what is the quantitative yield of 2D electrophoresis and how homogeneous this yield is for various classes of proteins. There are very few papers dealing with this issue, but one paper [18] showed that the yield of $2 \mathrm{D}$ electrophoresis was rather moderate (20$40 \%$ ), which is an often overlooked parameter when the overall efficiency of the system is considered. Furthermore, work on membrane proteins $[19,20]$ has strongly suggested 
that such losses are not homogeneous and may be much greater for poorly soluble proteins such as membrane proteins.

Of course, the overall yield of the process will also depend on the efficiency of the protein extraction during the sample preparation process, but this process is so variable from one experimental model to another that it is really beyond the scope of this chapter. Furthermore, this chapter will deal mainly with the quantification issues in 2D gel-based proteomics. Other important issues, such as the scope of gel-based proteomics, the interest of protein electrophoresis in modern proteomics and how electrophoresis systems can be modulated to improve their performances, have been reviewed elsewhere [21-23].

\section{The protein detection methods}

Over the years, numerous on-gel protein detection methods have been used, each having its advantages and drawbacks in the sensitivity/linearity/homogeneity/compatibility multiple criteria selection guide. Over the numerous years of use of $2 \mathrm{D}$ electrophoresis, some techniques have almost disappeared, while others are now standards in 2D gel-based proteomics. Many different protein detection schemes have been devised over the several decades of use of 2D gels [24], and only the most important ones will be reviewed in this chapter.

\subsection{Protein detection via radioisotopes}

This is an example of a technique that has subsided now, although it played a key role in the early days of proteomics, before the name was even coined.

Due to its exquisite sensitivity [25, 26] and linearity [27], protein detection via radioisotopes has been associated with almost all the early success stories of 2D electrophoresis, from the determination of protein numbers in cells [28], to the first identification of a protein from 2D gels, i.e. PCNA [29][30], to single cell proteomics [31] or to phosphoprotein studies [32]. These exquisite sensitivity and linearity have even increased with new detection technologies such as phosphor screens [33]. However, except for special purposes where it is almost irreplaceable [18, 34], detection via 
radioisotopes has almost disappeared from modern proteomics. In addition to the fact that not all samples are easily accessible to this type of detection (e.g. human samples), increasing safety and regulatory issues hastened the decline of radioactivity in proteomics.

\subsection{Protein detection via organic dyes}

In this mode of detection, the name of the game is to bind as many dye molecules per protein molecules as possible, in order to create a light absorption signal that is detectable. Of course, this process must be as reproducible as possible, and the molar extinction coefficient of the dye also plays a major role in the signal intensity.

For all these reasons, and despite a few attempts to use other dyes [35], colloidal Coomassie Blue, as introduced in 1988 by V. Neuhoff [36], reigns supreme in this subfield. However, its rather limited sensitivity requires high protein loads to be able to detect a decent number of spots, which results in turn in increased sample consumption and decreased separation performances due to protein precipitation, leading to various artifacts such as streaks, most often in the isoelectric focusing dimension.

\subsection{Protein detection via silver staining}

To alleviate the sensitivity problem mentioned above, while keeping the ease of use and low costs associated with methods dealing with visible light absorbance, silver staining was introduced a few years after 2D electrophoresis [37]. However, it is fair to say that the early days of silver staining were troublesome, with erratic backgrounds and sensitivities, and this was due to the complex chemical mechanisms prevailing in silver staining [38]. However, decisive progress was made at the end of the 80's [39], and silver staining is now a reliable technique allying high sensitivity, good reproducibility, low cost and ease of use [40]. This is further discussed in another chapter of this book (Chapter 6).

The main drawbacks of silver staining in modern proteomics are its limited dynamic range (see chapter 6) but also its weak compatibility with mass spectrometry [41, 42], although very high performances have been claimed [43]. It has been shown that the 
formaldehyde used in image development was the main culprit [44], and formadehydefree protocols have been developed that offer much increased compatibility with mass spectrometry [45] (see also chapter). In addition, the considerable increase of the sensitivity of the mass spectrometers over the years have decreased the severity of the problem.

\subsection{Protein detection via fluorescence}

To alleviate the problems shown by silver staining and Coomassie blue, protein detection by fluorescence has been developed and has shown great expansion over the past few years. Opposite to the strict mechanisms that prevail in visible staining, either with Coomassie Blue or with silver, protein detection via fluorescence can been achieved via multiple mechanisms, thereby offering great versatility to this technique.

The first and oldest mechanism is covalent binding, quite often of probes that are not fluorescent but become so when the covalent binding takes place [46, 47]. While the performances of such probes were not very impressive, and thus of limited use, a quantum leap was achieved when probes with much higher light absorption and emission characteristics were used. Furthermore, with the development of laser scanners, use of a set of closely related probes could be designed to achieve multiplexing [48], resulting in the very popular DIGE technique [49] (see also Chapter 7 in this book).

While this system has shown exquisite performances, it must be kept in mind that only a few fluorescent molecules are bound per protein molecule, resulting in an overall low signal intensity for many proteins. This is not a problem for pure detection, as the enormous contrast allow to use the full power of laser scanners, but this becomes a problem in some instances, e.g. spot excision for mass spectrometry, where more primitive illumination devices are used, e.g. UV tables.

Thus, another popular mode of protein detection via fluorescence uses non covalent binding, which takes place after migration and therefore does not interfere with protein 
migration, and which can also take place at much more numerous sites on the proteins, thereby resulting in a much higher signal, although the free fluorescent molecule remaining in the gels decreases the contrast, compared to covalent binding. Although other candidates have been recently proposed [50,51], two molecules dominate this field, namely epicocconone [52], and ruthenium based organometallic complexes [53], $[54,55]$. These molecules offer a detection sensitivity that is very close to that obtained with silver staining, with a much better linearity and a much better compatibility with mass spectrometry. However, in this latter aspect, they do not perform as well as Coomassie Blue [42].

While these two modes of detection (covalent and non-covalent binding) are light emission counterparts of modes that have been used in visible detection (light absorption) [56], there is a third detection mode that is specific to fluorescence, which is the use of environment-sensitive probes. These molecules that are used for protein detection do not fluorescence in polar environments such as water, but do fluoresce in less polar environments such as protein-SDS complexes. Several molecules have been shown to achieve protein detection in this general scheme. Protocols using protein fixing and denaturing conditions have been devised with some probes of the styryl class [57], [58], while completely non-denaturing conditions could be used for other probes such as Nile Red [59], carbazolyl vinyl dyes [60] and more recently carbocyanines [61].

While the fixing schemes offer no real advantage over the classical non covalent probes, the nondenaturing schemes offer distinct advantages such as speed, blotting ability [60] [61] and more importantly a very good sequence coverage in subsequent mass spectrometry [61].

Last but certainly not least, fluorescence can be used to detect specific motifs on gelseparated proteins, such as sugars [62] or phosphate groups [63], thereby offering a very wide palette of detection schemes with wide versatility.

3. The data analysis issues 
In most instances where 2D gel-based proteomics is used, the production of the gel image by any of the protein detection methods listed above is not the end of the story, and it is very uncommon that all detected protein spots are excised for protein identification by mass spectrometry. Most often, comparative image analysis is used to determine a few spots whose expression profile within the complete experiment matches biologically relevant events. This image analysis process can be split in four major steps. First data acquisition [4], then spot detection and quantification [5], then gel matching [6] (although gel matching can be carried out prior to spot detection in some analysis systems) and finally data analysis [7]. It must be stressed that this image analysis process has been used very early after the introduction of 2D gel electrophoresis $[3,64$, $65]$, quite often with sophisticated data analysis tools [7, 8, 66, 67], long before the word proteomics even existed.

Although very cumbersome at these early times, image analysis has dramatically progressed over the years, greatly helped by the considerable increase in computer power. However, image analysis is very dependent on the quality of the experimental data, and especially on their reproducibility. In this respect, the generalization of immobilized $\mathrm{pH}$ gradient has had a major impact by bringing a level of positional reproducibility that could never be achieved with conventional isoelectric focusing with ampholytes [68-70]. However, image reproducibility is a complex process, and even with the use of immobilized $\mathrm{pH}$ gradients, reproducibility is maximized by parallelizing the gels in dedicated instruments [71]. Fortunately enough, such parallel electrophoresis instruments had been developed during the early days of 2D electrophoresis [72, 73], when the inter-run variability was very high.

Even though the reproducibility of $2 \mathrm{D}$ gel-based proteomics is much higher than for other setups, as shown by higher requirements [74] and stricter practices [75], there is an important concern that has emerged over the past few years, i.e. the problem of false positives. Although false positives can have an experimental origin [76], a certain proportion is due to the statistical processes used to determine modulated spots, and thus to the problem of multiple testing [77-79]. Although purely statistical tools such as false discovery estimates have been proposed to address this concern [77-79], these tools are not completely well-adapted to the analysis of 2D gel images [80]. 
In this game of quantitative image analysis to determine spots that show changes in the biological process of interest and thus deserve further studies there is another experimental parameter that plays a key role besides separation reproducibility, namely sample variability and especially biological variability, i.e. from one biological sample to another, before any technical variability introduced by the protein extraction process. This variability grows along with two parameters. One is the plasticity of the proteome, so that variability is often greater in cultured prokaryotic cells than in mammalian ones, as a consequence of the much shorter generation times. The second factor is of course the physiological and genetic heterogeneity, so that in vitro systems are less variable than in vivo systems on inbred laboratory animals, which are in turn less variable than samples obtained in conditions where neither the precise physiological state nor the genetic background can be controlled (typically human samples). In some of the latter cases, the biological variability is so high that it becomes very difficult to find any protein spots showing a statistically significant variation in the experimental process. In such cases, it is tempting to pool samples within the same experimental group, in order to average out the biological variability and facilitate the discovery of modulated proteins. However, it must be kept in mind that interindividual variations are an important part of the problems that do exist in clinics. Thus, this factor cannot be evacuated easily, and pooling must be carefully understood and controlled to achieve correct results [81, 82].

\section{The protein unicity issue}

In the early days of protein identification from 2D gel spots, e.g. by Edman sequencing or low sensitivity mass spectrometry, the situation was simple: at most one protein was detected per spot. With the increase of sensitivity of the mass spectrometers, several proteins are more and more often identified from one 2D gel spots. This has been perceived as a problem by some scientists [83], but not by others [84]. Data obtained under the worst conditions, i.e. with sub-milligram protein loads and a high sensitivity mass spectrometer, have shown that in most of the cases, the protein identified with the most peptides in one spot accounts for more than $75 \%$ of the mass spectrometry signal, so that a "winner-takes-all" protein assignment scheme is legitimate in most cases. In the rare cases where there is still ambiguity from the mass spectrometry signal, an 
additional separation of the spot(s) of interest can be carried out to settle the matter [85]

\section{Conclusions}

At the beginning of the 21 st century, $2 \mathrm{D}$ gel-based proteomics is often depicted as an outdated technique, on the basis of its poor ability to analyze membrane proteins [86] and of its moderate analysis depth [87], [88]. However, in the landscape of proteomic techniques, it still offers unique advantages that make it stand apart (and ahead) of the other proteomic setups for many applications. For example, it is the simplest technique that is able to resolve complete proteins with their trail and combination of posttranslational modifications, including protein fragmentation, and this unique ability should be highly valued with our increased knowledge on the importance of post-translational modifications on protein activity. This ability has been used in a variety of studies (reviewed in [22]). Thus, 2D gel-based proteomics has still a lot to offer to the researchers who will be able to use its strengths. 


\section{References}

[1] MacGillivray AJ, Rickwood D (1974) The heterogeneity of mouse-chromatin nonhistone proteins as evidenced by two-dimensional polyacrylamide-gel electrophoresis and ion-exchange chromatography. Eur J Biochem 41 (1):181-190

[2] O'Farrell PH (1975) High resolution two-dimensional electrophoresis of proteins. J Biol Chem 250 (10):4007-4021

[3] Anderson NL, Taylor J, Scandora AE, Coulter BP, Anderson NG (1981) The TYCHO system for computer analysis of two-dimensional gel electrophoresis patterns. Clin Chem 27 (11):1807-1820

[4] Vincens P, Paris N, Pujol JL, Gaboriaud C, Rabilloud T, Pennetier JL, Matherat P, Tarroux P (1986) Hermes - a 2nd Generation Approach to the Automatic-Analysis of Two-Dimensional Electrophoresis Gels .1. Data Acquisition. Electrophoresis 7 (8):347356

[5] Vincens P (1986) Hermes - a 2nd Generation Approach to the Automatic-Analysis of Two-Dimensional Electrophoresis Gels .2. Spot Detection and Integration. Electrophoresis 7 (8):357-367

[6] Vincens P, Tarroux P (1987) Hermes - a 2nd Generation Approach to the AutomaticAnalysis of Two-Dimensional Electrophoresis Gels .3. Spot List Matching. Electrophoresis 8 (2):100-107

[7] Tarroux P, Vincens P, Rabilloud T (1987) Hermes - a 2nd Generation Approach to the Automatic-Analysis of Two-Dimensional Electrophoresis Gels .4] Data-Analysis. Electrophoresis 8 (4):187-199

[8] Pun T, Hochstrasser DF, Appel RD, Funk M, Villars-Augsburger V, Pellegrini C (1988) Computerized classification of two-dimensional gel electrophoretograms by correspondence analysis and ascendant hierarchical clustering. Appl Theor Electrophor $1(1): 3-9$

[9] Matsudaira P (1987) Sequence from picomole quantities of proteins electroblotted onto polyvinylidene difluoride membranes. J Biol Chem 262 (21):10035-10038

[10] Aebersold RH, Leavitt J, Saavedra RA, Hood LE, Kent SBH (1987) Internal AminoAcid Sequence-Analysis of Proteins Separated by One-Dimensional or TwoDimensional Gel-Electrophoresis after Insitu Protease Digestion on Nitrocellulose. Proceedings of the National Academy of Sciences of the United States of America 84 (20):6970-6974

[11] Aebersold RH, Pipes G, Hood LE, Kent SBH (1988) N-Terminal and Internal Sequence Determination of Microgram Amounts of Proteins Separated by IsoelectricFocusing in Immobilized Ph Gradients. Electrophoresis 9 (9):520-530

[12] Rosenfeld J, Capdevielle J, Guillemot JC, Ferrara P (1992) In-gel digestion of proteins for internal sequence analysis after one- or two-dimensional gel electrophoresis. Anal Biochem 203 (1):173-179

[13] Rasmussen HH, van Damme J, Puype M, Gesser B, Celis JE, Vandekerckhove J (1992) Microsequences of 145 proteins recorded in the two-dimensional gel protein database of normal human epidermal keratinocytes. Electrophoresis 13 (12):960-969 [14] Yates JR, Eng JK, McCormack AL, Schieltz D (1995) Method to Correlate Tandem Mass-Spectra of Modified Peptides to Amino-Acid-Sequences in the Protein Database. Analytical Chemistry 67 (8):1426-1436 
[15] Yates JR, McCormack AL, Schieltz D, Carmack E, Link A (1997) Direct analysis of protein mixtures by tandem mass spectrometry. Journal of Protein Chemistry 16 (5):495497

[16] Rogowska-Wrzesinska A, Le Bihan MC, Thaysen-Andersen M, Roepstorff P (2013) 2D gels still have a niche in proteomics. J Proteomics 88:4-13

[17] Smolka M, Zhou H, Aebersold R (2002) Quantitative protein profiling using twodimensional gel electrophoresis, isotope-coded affinity tag labeling, and mass spectrometry. Mol Cell Proteomics 1 (1):19-29

[18] Zhou SB, Bailey MJ, Dunn MJ, Preedy VR, Emery PW (2005) A quantitative investigation into the losses of proteins at different stages of a two-dimensional gel electrophoresis procedure. Proteomics 5 (11):2739-2747

[19] Santoni V, Molloy M, Rabilloud T (2000) Membrane proteins and proteomics: Un amour impossible? Electrophoresis 21 (6):1054-1070

[20] Eravci M, Fuxius S, Broedel O, Weist S, Krause E, Stephanowitz H, Schluter H, Eravci S, Baumgartner A (2008) The whereabouts of transmembrane proteins from rat brain synaptosomes during two-dimensional gel electrophoresis. Proteomics 8 (9):17621770

[21] Rabilloud T, Vaezzadeh AR, Potier N, Lelong C, Leize-Wagner E, Chevallet M (2009) Power and limitations of electrophoretic separations in proteomics strategies. Mass Spectrom Rev 28 (5):816-843

[22] Rabilloud T, Chevallet M, Luche S, Lelong C (2010) Two-dimensional gel electrophoresis in proteomics: past, present and future. J Proteomics 73 (11):2064-2077 [23] Rabilloud T (2010) Variations on a theme: changes to electrophoretic separations that can make a difference. J Proteomics 73 (8):1562-1572

[24] Miller I, Crawford J, Gianazza E (2006) Protein stains for proteornic applications: Which, when, why? Proteomics 6 (20):5385-5408

[25] Bonner WM, Laskey RA (1974) Film Detection Method for Tritium-Labeled Proteins and Nucleic-Acids in Polyacrylamide Gels. European Journal of Biochemistry 46 (1):8388

[26] Perng GS, Rulli RD, Wilson DL, Perry GW (1988) A Comparison of Fluorographic Methods for the Detection of S-35-Labeled Proteins in Polyacrylamide Gels. Analytical Biochemistry 173 (2):387-392

[27] Laskey RA, Mills AD (1975) Quantitative Film Detection of H-3 and C-14 in Polyacrylamide Gels by Fluorography. European Journal of Biochemistry 56 (2):335-341 [28] Duncan R, McConkey EH (1982) How many proteins are there in a typical mammalian cell? Clin Chem 28 (4 Pt 2):749-755

[29] Bravo R, Fey SJ, Bellatin J, Larsen PM, Arevalo J, Celis JE (1981) Identification of a nuclear and of a cytoplasmic polypeptide whose relative proportions are sensitive to changes in the rate of cell proliferation. Exp Cell Res 136 (2):311-319

[30] Bravo R, Frank R, Blundell PA, Macdonald-Bravo H (1987) Cyclin/PCNA is the auxiliary protein of DNA polymerase-delta. Nature 326 (6112):515-517

[31] Bravo R, Fey SJ, Small JV, Larsen PM, Celis JE (1981) Coexistence of 3 Major Isoactins in a Single Sarcoma-180 Cell. Cell 25 (1):195-202

[32] Sobel A, Tashjian AH, Jr. (1983) Distinct patterns of cytoplasmic protein phosphorylation related to regulation of synthesis and release of prolactin by $\mathrm{GH}$ cells. $\mathrm{J}$ Biol Chem 258 (17):10312-10324

[33] Patterson SD, Latter Gl (1993) Evaluation of Storage Phosphor Imaging for 
Quantitative-Analysis of 2-D Gels Using the Quest-li System. Biotechniques 15 (6):1076\&

[34] Zhou SB, Mann CJ, Dunn MJ, Preedy VR, Emery PW (2006) Measurement of specific radioactivity in proteins separated by two-dimensional gel electrophoresis. Electrophoresis 27 (5-6):1147-1153

[35] Choi JK, Tak KH, Jin LT, Hwang SY, Kwon TI, Yoo GS (2002) Background-free, fast protein staining in sodium dodecyl sulfate polyacrylamide gel using counterion dyes, zincon and ethyl violet. Electrophoresis 23 (24):4053-4059

[36] Neuhoff V, Arold N, Taube D, Ehrhardt W (1988) Improved staining of proteins in polyacrylamide gels including isoelectric focusing gels with clear background at nanogram sensitivity using Coomassie Brilliant Blue G-250 and R-250] Electrophoresis 9 (6):255-262

[37] Switzer RC, Merril CR, Shifrin S (1979) Highly Sensitive Silver Stain for Detecting Proteins and Peptides in Polyacrylamide Gels. Analytical Biochemistry 98 (1):231-237

[38] Rabilloud T (1990) Mechanisms of Protein Silver Staining in Polyacrylamide Gels - a 10-Year Synthesis. Electrophoresis 11 (10):785-794

[39] Blum H, Beier H, Gross HJ (1987) Improved Silver Staining of Plant-Proteins, Rna and DNA in Polyacrylamide Gels. Electrophoresis 8 (2):93-99

[40] Chevallet M, Luche S, Rabilloud $T$ (2006) Silver staining of proteins in polyacrylamide gels. Nat Protoc 1 (4):1852-1858

[41] Scheler C, Lamer S, Pan Z, Li XP, Salnikow J, Jungblut P (1998) Peptide mass fingerprint sequence coverage from differently stained proteins on two-dimensional electrophoresis patterns by matrix assisted laser desorption/ionization-mass spectrometry (MALDI-MS). Electrophoresis 19 (6):918-927

[42] Chevalier F, Centeno D, Rofidal V, Tauzin M, Martin O, Sommerer N, Rossignol M (2006) Different impact of staining procedures using visible stains and fluorescent dyes for large-scale investigation of proteomes by MALDI-TOF mass spectrometry. J Proteome Res 5 (3):512-520

[43] Shevchenko A, Wilm M, Vorm O, Mann M (1996) Mass spectrometric sequencing of proteins from silver stained polyacrylamide gels. Analytical Chemistry 68 (5):850-858

[44] Richert S, Luche S, Chevallet M, Van Dorsselaer A, Leize-Wagner E, Rabilloud T (2004) About the mechanism of interference of silver staining with peptide mass spectrometry. Proteomics 4 (4):909-916

[45] Chevallet M, Luche S, Diemer H, Strub JM, Van Dorsselaer A, Rabilloud T (2008)

Sweet silver: A formaldehyde-free silver staining using aldoses as developing agents, with enhanced compatibility with mass spectrometry. Proteomics 8 (23-24):4853-4861

[46] Jackowski G, Liew CC (1980) Fluorescamine Staining of Non-Histone Chromatin Proteins as Revealed by Two-Dimensional Polyacrylamide-Gel Electrophoresis. Analytical Biochemistry 102 (2):321-325

[47] Urwin VE, Jackson P (1991) A Multiple High-Resolution Mini 2-Dimensional Polyacrylamide-Gel Electrophoresis System - Imaging 2-Dimensional Gels Using a Cooled Charge-Coupled Device after Staining with Silver or Labeling with Fluorophore. Analytical Biochemistry 195 (1):30-37

[48] Unlu M, Morgan ME, Minden JS (1997) Difference gel electrophoresis: a single gel method for detecting changes in protein extracts. Electrophoresis 18 (11):2071-2077 [49] Tonge R, Shaw J, Middleton B, Rowlinson R, Rayner S, Young J, Pognan F, Hawkins E, Currie I, Davison M (2001) Validation and development of fluorescence two- 
dimensional differential gel electrophoresis proteomics technology. Proteomics 1 (3):377-396

[50] Suzuki Y, Yokoyama K (2008) Design and synthesis of ICT-based fluorescent probe for high-sensitivity protein detection and application to rapid protein staining for SDSPAGE. Proteomics 8 (14):2785-2790

[51] Cong WT, Jin LT, Hwang SY, Choi JK (2008) Fast fluorescent staining of protein in sodium dodecyl sulfate polyacrylamide gels by palmatine. Electrophoresis 29 (2):417423

[52] Mackintosh JA, Choi HY, Bae SH, Veal DA, Bell PJ, Ferrari BC, Van Dyk DD, Verrills NM, Paik YK, Karuso P (2003) A fluorescent natural product for ultra sensitive detection of proteins in one-dimensional and two-dimensional gel electrophoresis. Proteomics 3 (12):2273-2288

[53] Berggren K, Chernokalskaya E, Steinberg TH, Kemper C, Lopez MF, Diwu Z, Haugland RP, Patton WF (2000) Background-free, high sensitivity staining of proteins in one- and two-dimensional sodium dodecyl sulfate-polyacrylamide gels using a luminescent ruthenium complex. Electrophoresis 21 (12):2509-2521

[54] Rabilloud T, Strub JM, Luche S, van Dorsselaer A, Lunardi J (2001) Comparison between Sypro Ruby and ruthenium II tris (bathophenanthroline disulfonate) as fluorescent stains for protein detection in gels. Proteomics 1 (5):699-704

[55] Lamanda A, Zahn A, Roder D, Langen H (2004) Improved Ruthenium II tris (bathophenantroline disulfonate) staining and destaining protocol for a better signal-tobackground ratio and improved baseline resolution. Proteomics 4 (3):599-608

[56] Fazekas SDS, Webster RG, Datyner A (1963) 2 New Staining Procedures for Quantitative Estimation of Proteins on Electrophoretic Strips. Biochimica Et Biophysica Acta 71 (2):377-391

[57] Steinberg TH, Jones LJ, Haugland RP, Singer VL (1996) SYPRO Orange and SYPRO Red protein gel stains: One-step fluorescent staining of denaturing gels for detection of nanogram levels of protein. Analytical Biochemistry 239 (2):223-237

[58] Malone JP, Radabaugh MR, Leimgruber RM, Gerstenecker GS (2001) Practical aspects of fluorescent staining for proteomic applications. Electrophoresis 22 (5):919932

[59] Daban JR, Bartolome S, Samso M (1991) Use of the Hydrophobic Probe Nile Red for the Fluorescent Staining of Protein Bands in Sodium Dodecyl-Sulfate Polyacrylamide Gels. Analytical Biochemistry 199 (2):169-174

[60] Steinberg TH, Lauber WM, Berggren K, Kemper C, Yue S, Patton WF (2000) Fluorescence detection of proteins in sodium dodecyl sulfate-polyacrylamide gels using environmentally benign, nonfixative, saline solution. Electrophoresis 21 (3):497-508

[61] Luche S, Lelong C, Diemer H, Van Dorsselaer A, Rabilloud T (2007) Ultrafast coelectrophoretic fluorescent staining of proteins with carbocyanines. Proteomics 7 (18):3234-3244

[62] Hart C, Schulenberg B, Steinberg TH, Leung WY, Patton WF (2003) Detection of glycoproteins in polyacrylamide gels and on electroblots using Pro-Q Emerald 488 dye, a fluorescent periodate Schiff-base stain. Electrophoresis 24 (4):588-598

[63] Schulenberg B, Goodman TN, Aggeler R, Capaldi RA, Patton WF (2004) Characterization of dynamic and steady-state protein phosphorylation using a fluorescent phosphoprotein gel stain and mass spectrometry. Electrophoresis 25 (15):2526-2532 
[64] Garrels JI (1979) Two dimensional gel electrophoresis and computer analysis of proteins synthesized by clonal cell lines. J Biol Chem 254 (16):7961-7977

[65] Vo KP, Miller MJ, Geiduschek EP, Nielsen C, Olson A, Xuong NH (1981) Computer analysis of two-dimensional gels. Anal Biochem 112 (2):258-271

[66] Tarroux P (1983) Analysis of Protein-Patterns During Differentiation Using 2-D Electrophoresis and Computer Multidimensional Classification. Electrophoresis 4 (1):6370

[67] Appel R, Hochstrasser D, Roch C, Funk M, Muller AF, Pellegrini C (1988) Automatic classification of two-dimensional gel electrophoresis pictures by heuristic clustering analysis: a step toward machine learning. Electrophoresis 9 (3):136-142

[68] Corbett JM, Dunn MJ, Posch A, Gorg A (1994) Positional Reproducibility of Protein Spots in 2-Dimensional Polyacrylamide-Gel Electrophoresis Using Immobilized $\mathrm{Ph}$ Gradient Isoelectric-Focusing in the First Dimension - an Interlaboratory Comparison. Electrophoresis 15 (8-9):1205-1211

[69] Blomberg A, Blomberg L, Norbeck J, Fey SJ, Larsen PM, Larsen M, Roepstorff P, Degand H, Boutry M, Posch A, Gorg A (1995) Interlaboratory Reproducibility of Yeast Protein-Patterns Analyzed by Immobilized Ph Gradient 2-Dimensional GelElectrophoresis. Electrophoresis 16 (10):1935-1945

[70] Choe LH, Lee KH (2003) Quantitative and qualitative measure of intralaboratory two-dimensional protein gel reproducibility and the effects of sample preparation, sample load, and image analysis. Electrophoresis 24 (19-20):3500-3507

[71] Eravci M, Fuxius S, Broedel O, Weist S, Eravci S, Mansmann U, Schluter H, Tiemann J, Baumgartner A (2007) Improved comparative proteome analysis based on two-dimensional gel electrophoresis. Proteomics 7 (4):513-523

[72. Anderson NG, Anderson NL (1978) Analytical Techniques for Cell Fractions .21. 2Dimensional Analysis of Serum and Tissue Proteins - Multiple Isoelectric-Focusing. Analytical Biochemistry 85 (2):331-340

[73] Anderson NL, Anderson NG (1978) Analytical Techniques for Cell Fractions .22. 2Dimensional Analysis of Serum and Tissue Proteins - Multiple Gradient-Slab GelElectrophoresis. Analytical Biochemistry 85 (2):341-354

[74] Celis JE (2004) Gel-based proteomics: what does MCP expect? Mol Cell Proteomics 3 (10):949

[75] Hackett $M$ (2008) Science, marketing and wishful thinking in quantitative proteomics. Proteomics 8 (22):4618-4623

[76] Fuxius S, Eravci M, Broedel O, Weist S, Mansmann U, Eravci S, Baumgartner A (2008) Technical strategies to reduce the amount of "false significant" results in quantitative proteomics. Proteomics 8 (9):1780-1784

[77] Karp NA, Lilley KS (2007) Design and analysis issues in quantitative proteomics studies. Proteomics 7 Suppl 1:42-50

[78] Karp NA, McCormick PS, Russell MR, Lilley KS (2007) Experimental and statistical considerations to avoid false conclusions in proteomics studies using differential in-gel electrophoresis. Mol Cell Proteomics 6 (8):1354-1364

[79] Eravci M, Mansmann U, Broedel O, Weist S, Buetow S, Wittke J, Brunkau C, Hummel M, Eravci S, Baumgartner A (2009) Strategies for a Reliable Biostatistical Analysis of Differentially Expressed Spots from Two-Dimensional Electrophoresis Gels. Journal of Proteome Research 8 (5):2601-2607

[80] Diz AP, Carvajal-Rodriguez A, Skibinski DO (2011) Multiple hypothesis testing in 
proteomics: a strategy for experimental work. Mol Cell Proteomics 10 (3):M110 004374 [81] Diz AP, Truebano M, Skibinski DO (2009) The consequences of sample pooling in proteomics: an empirical study. Electrophoresis 30 (17):2967-2975

[82] Karp NA, Lilley KS (2009) Investigating sample pooling strategies for DIGE experiments to address biological variability. Proteomics 9 (2):388-397

[83] Campostrini N, Areces LB, Rappsilber J, Pietrogrande MC, Dondi F, Pastorino F, Ponzoni M, Righetti PG (2005) Spot overlapping in two-dimensional maps: a serious problem ignored for much too long. Proteomics 5 (9):2385-2395

[84] Hunsucker SW, Duncan MW (2006) Is protein overlap in two-dimensional gels a serious practical problem? Proteomics 6 (5):1374-1375

[85] Colignon B, Raes M, Dieu M, Delaive E, Mauro S (2013) Evaluation of threedimensional gel electrophoresis to improve quantitative profiling of complex proteomes. Proteomics 13 (14):2077-2082

[86] Rabilloud T (2009) Membrane proteins and proteomics: love is possible, but so difficult. Electrophoresis 30 Suppl 1:S174-180

[87] Petrak J, Ivanek R, Toman O, Cmejla R, Cmejlova J, Vyoral D, Zivny J, Vulpe CD (2008) Deja vu in proteomics. A hit parade of repeatedly identified differentially expressed proteins. Proteomics 8 (9):1744-1749

[88] Wang P, Bouwman FG, Mariman EC (2009) Generally detected proteins in comparative proteomics--a matter of cellular stress response? Proteomics 9 (11):29552966 